1917

Dickey

A New Amphibian Cestode 



\title{
A NEW AMPHIBIAN CESTODE
}

$$
\text { BY }
$$

\author{
LLOYD BLACKWELL DICKEY
}

A. B. Fargo College, 1915

\section{THESIS}

Submitted in Partial Fulfillment of the Requirements for the

$$
\text { Degree of }
$$

MASTER OF ARTS

IN ZOOLOGY

THE GRADUATE SCHOOL

OF THE

\section{UNIVERSITY OF ILLINOIS}


Digitized by the Internet Archive in 2013 


\section{7 \\ I] 55}

\section{U N I V E R I T Y OF I L L I NOIS \\ THE GRADUATE SCHOOL}

Sune 1. . . 1917.

I HEREBY RECOMMEND THAT THE THESIS PREPARED UNDER MY SUPERVISION BY Iloyd Blackwell Dickey

ENTITLED .... A NEW ANPH IBIAN CESTODE

BE ACCEPTED AS FULFILLING THIS PART OF THE REQUIREMENTS FOR THE DEGREE OF Naster of Arts

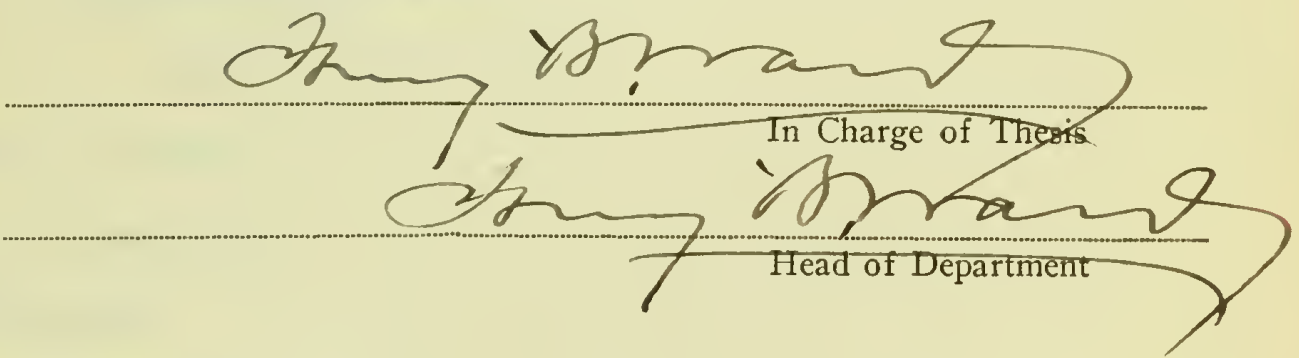

Recommendation concurred in :*

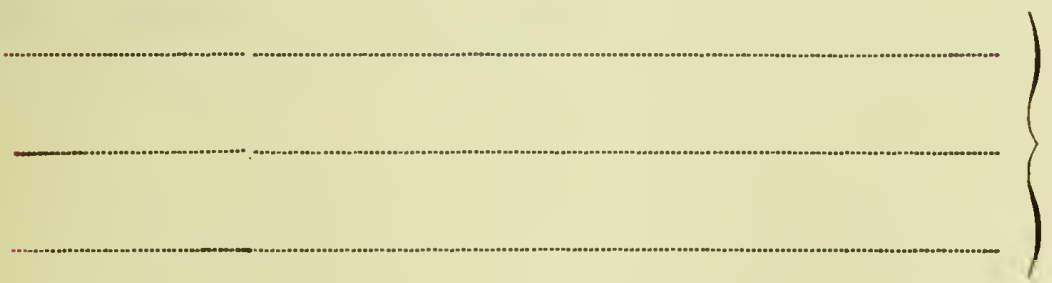

Committee

on

Final Examination*

*Required for doctor's degree but not for master's. 
(2)

tot 


\section{TABLE OF CONTENTS}

I Introduction

II Review of Previous Work on Related Forms

II Material and Technique

IV Morphology of New Form

General Appearance and Weasurements Scolex

Cuticula

Subcuticula

Musculature

Excretory System

Nervous System

Reproductive System

Nale organs

Female Organs

Parauterine Organs

$\mathrm{V}$ Comparison of Forms

VI Systematic Position

VII Acknowledgments

VIII Iiterature Cited

IX Explanation of Plate 

A NEW AMPHIBIAIT CESTODE

\section{INTRODUCT ION}

The material upon which the following study is based, was collected at Oxford, Georgia, in July, 1916. It consisted of parts of twenty-two tapeworms, eleven adult, and eleven immature. These were secured from two host specimens of Bufo lentiginosus, which is the common southern species of toad. The worms were killed in cold corrosive acetic sublimate, and preserved in $85 \%$ alcohol. There has been no opportunity for studying the parasites alive.

\section{REVIEW OF PREVIOUS FORK ON RELATED FORMS}

But few species of cestodes from amphibian hosts have ever been described, and of these, but five are from Anurans. Nematotaenia dispar (Goeze 1782) has been reported from Europe by Schmidt (1855), and Fuhrmann (1895), and from America by Stiles and Hassall (1912; 277). Both Schmidt and Fuhrmann simply state that the parasite is found in frogs and toads, while stiles and Hassall specify the following hosts: Rana temporaria; Bufo vulgaris; Bufo viridis; Pelobates fuscas; Hyla arborea; Salamandra atra; Rana halecina; Bufo americanus; Necturus maculatus. Taenia pulchella Leidy 1851, was reported from America, in Bufo americanus, at the time of its original description. Jewell (1916) reports and describes Cylindrotaenia americana from America in Acris grylis, Rana pipiens, Rana virescens, and Bufo lentiginosus. These three species, together with two Proteocephalids, Ophiotaenia hylae from 

Australia, and 0. schultzei from Africa (Johnston 1912), constitute all the species so far described from frogs and toads. Johnston (1916; 194) reports the presence of a new species of Nematotaenia in Australia, which人not as yet been described. Larval stages of Sparganum have been known to occur in European frogs. Absolutely nothing is known of the larval stages of any of the adult cestodes thus far reported in Anurans.

Jewell (1916) has pointed out the discrepancies of Schmidt's description of Nematotaenia dispar (Schmidt 1855) as compared with the recognized, original form reported and described by Goeze (1782), which was later described by Fuhrmann (1895). It is probable that Schmidt's material was not Nematotaenia dispar, as he describes the worm as having a neck, the greatest diameter being at the posterior end, and with an oval cirrus sac about twice as long as broad. Fuhrmann's description includes a worm devoid of a neck, the greatest diameter of the strobila being at the anterior end, and with a cirrus sac about ten times as long as broad.

Luehe proposed the genus Nematotaenia, to contain Taenia dispar Goeze (Iuehe 1899: 526). His first characterization of the new genus, however, appears in a later paper (Iuehe 1910), as follows: "Taenien mit unbewaffnetem Scolex, ohne Rostellum, mit drehrundem Korper, der in seinem vorderen Abschnitt etwas dicker ist und nach hinten allmallich dinner und schliesslich fadenformig wird. Gliederung nur am Hịterende ausgesprochen, wo sich die reifen Froglottiden, die wesentlich langer als breit sind, einzeln ablosen, um dann lebhaft beweglich noch langere zeit weiterzuleben. Geschlecht8dffnungen randstlindig, unregelmässig abwechselnd. Hoden 

in der Zweizahl, dorsal und annahernd symmetrisch. Dotterstock fast genau in der Achse des KOrpers; Keimstock ventral, der Genitaldffnung wenig genthert. Geschlechtswege dorsal von Wassergeftssen und Markstrangen. Uterus frahzeitig in einzelne Eikapseln zerfallend, welche je 2-4 (meist 3 ) Eier enthalten. Eier mit 3 HHllen. Finnenstadium unbekannt.

Im Darm von Amphibien. Bisher nur eine Art bekannt." Jewell (1916:191) gives the following diagnosis for Cylindrotaenia: "Scolex unarmed, without rostellum; reproductive organs single in each proglottid; pores lateral, alternating; vagina and cirrus dorsal to the excretory canals and main nerve trunk; test is one, dorsal; ovary and vitellaria ventral. Uterus breaks up into capsules surrounding the embryos which ultimately pass into two parauterine capsules." Cylindrotaenia americana "from the small intestine of various Anura," is designated as the type.

Apparently the only published description of Taenia pulchella is the original one by Leidy (1851:24l) as follows: "White, without admixture of any other color, variable, usually broadest anteriorly. Head quadrilateral, subclavate, obtusely rounded, broader than neck. Acetabula circular, cupshaped, lateral and opposite, sessile, protractile. Neck very long, cylindroid. Articuli containing several colorless globules; anteriorly subglobular or transversely oval; posteriorly moniliform, longitudinally oval, or cylindroid and generally incrassate. Entire length, 50.8 to $238.6 \mathrm{~mm}$. Scolex, diameter $0.34 \mathrm{~mm}$. Acetabula, 0.127 to $0.153 \mathrm{~mm}$. Ripe proglottids, length $0.34 \mathrm{mr}$; d diameter 0.254 to $0.53 \mathrm{~mm}$. Ripe proglottids, length 0.53 to $0.57 \mathrm{~mm}$ : ; diameter 0.19 to $0.34 \mathrm{~mm}$. Host Bufo americanus.

Closely resembles Taenia dispar Goeze, found in Bufo 

viridus etc., but it is relatively longer and narrower and is never colored."

\section{MATERIAL AND TECHNIQUE}

The worms, as previously noted, were killed in cold aceticsublimate, and preserved in $85 \%$ alcohol. Sections were made in three directions, transverse, sagittal, and frontal. In all three directions the sections were cut 9 or $10 \mu$ thick. The toto preparations were stained in Ehrlich's acid haematoxylin, destained in weak acid alcohol, cleared in oil of wintergreen, and mounted in dammar. In the sectioned specimens, Heiderihain's Iron-Alum Haematoxylin method was used for the nuclear stain and orange G. in absolute alcohol as a counterstain. In some instances satisfactory material was obtained without the employment of any counterstain whatsoever. Both the xylol-paraffin and the oll of cedar-paraffin methods were used, with equal success. 

MORPHOIOGY OF THE NEW FORN

General Appearance and Measurements. Two adult specimens of the worm, both bearing ripe proglottides, each measured about $100 \mathrm{~mm}$. in length. There were many ripe proglottides in the collection, but these presumably became detached in collecting, but from other specimens, so that $100 \mathrm{~mm}$. may be assumed to be the approximate maximum length. There were eleven joung worms in the material, varying in length from $3.5 \mathrm{~mm}$. to $5 \mathrm{~mm}$., with an average of about $4 \mathrm{~mm}$. These were all collected from a single host.

The worm is cylindrical in form, in the region immediately posterior to the suckers and the base of the scolex. In the region of the strobila where the reproductive organs attain their maximum development, the segments are oval in cross-section, being compressed laterally (Fig. 4). Thus, in a typical specimen, at a distance of about $6 \mathrm{~mm}$. from the tip of the scolex, the dorso-ventral diameter and the transverse diameter are both $0.48 \mathrm{~mm}$. At a distance of 13. mm., the dorso-ventral diameter is $0.57 \mathrm{~mm}$, the transverse diameter $0.33 \mathrm{~mm}$., while at $40 \mathrm{~mm}$. the circular form is again assumed, the diameter here being approximately $0.5 \mathrm{~mm}$. In this region the eggs have passed into the parauterine capsules and the uterus has broken up. From this region to the end of the strobila the circular form is maintained. In a few specimens the greatest compression is much less marked, the dorso-ventral diameter in some being $0.44 \mathrm{mr}$. and the transverse diameter $0.39 \mathrm{~mm}$. From the foregoing measurements it is seen that the change in proportional diameter is not due to growth, but to either compression or contraction, occurring, possibly, in the preservation of the material. 

The greatest dorso-ventral diameter, 0.65 to $0.74 \mathrm{~mm}$. occurs in the anterior portion of the strobila, about $20 \mathrm{~mm}$. from the tip of the scolex. The genital segments in this region measure 0.085 to $0.095 \mathrm{~mm}$. in length. In these, the eggs have passed into the uterus. No external proglottidation is apparent in the anterior region of the worm. It occurs rather distinctly from 48 to $60 \mathrm{~mm}$. from the scolex, where the segments begin to elongate. Here they measure $0.24 \mathrm{~mm}$ in length, and $0.39 \mathrm{mrn}$. in diameter. The length of the last few proglottides of the strobila and of the detached proglottides exceeds the diameter considerably, the length being 0.58 to $0.66 \mathrm{~mm}$. and the diameter 0.18 to $0.24 \mathrm{~mm}$.

In color the worm is creamy white throughout. Scolex. The scolex is unarmed, spherical, and broader than the neck. In adult specimens it measures 0.62 to $0.52 \mathrm{~mm}$. in diameter. The neck averages $0.48 \mathrm{~mm}$. in width. In the young worms the diameter of the scolex is 0.33 to $0.26 \mathrm{~mm}$. The suckers are situated near the tip of the scolex, consequently anterior to the greatest diameter of the latter (Fig. 1). They are unarmed, and have a diameter in the adult forms, of from $0.141 \mathrm{~mm}$. to 0.093 $\mathrm{mm}$. The diameter of the suckers in the young worms is from 0.085 to $0.09 \mathrm{~mm}$. The lumen is directed anteriad and slightly laterad. The scolex is circular in cross-section, except through the region of the suckers, where it is slightly oval (Fig. 3.). Two shallow grooves occur on opposite siles of the scolex. These extend from the tip of the scolex to the base of the suckers.

Cuticula. From the material at hand it appears that the cuticula is two-layered, both layers being of equal thickness. No layer could be discerned between what appeared to be an outer and and an inner layer. The outer layer stains more heavily. The 

cuticula is 4 to $5 \mu$ in thickness and is supported by a delicate basement membrane.

Subcuticula. The subcuticula consists of cells $0.032 \mathrm{~mm}$. long and $0.004 \mathrm{~mm}$. in diameter. The nuclei are large and stain less heavily than the rest of the cells.

Musculature. The longitudinal muscles are well developed, and arranged in a single layer. They separate the parenchyma into a cortical and a medullary area. The latter averages about $0.296 \mathrm{~mm}$. in dorso-ventral diameter and about $0.222 \mathrm{~mm}$. in lateral diameter in the region where the reproductive organs attain their maximum development. The longitudinal strands occur at approximately $0.083 \mathrm{~mm}$. from the cuticula. Several small strands (about five or $s i x)$ go to make up a large bundle, these occurring at more or less regular intervals. Between 50 and 60 of these bundles may be seen in a cross-section. Many of them may be seen to extend from one segment to another.

Between the subcuticula and the cuticula the longitudinal fibres of the subcuticular muscles can barely be discerned. No trace of dorso-ventral muscles was found.

The musculature of the scolex is well developed. The muscle strands of the longitudinal system are here seen to be large and numerous. They have no definite arrangement and are massed together at the tip of the scolex so that a cross-section of the tip shows them as numerous longitudinal strands. In addition to the longitudinal muscles there are transverse muscles running concentric with the basement membrane of the suckers. Other transverse muscles may be observed, but their course could not be followed. Excretory System. The ventral excretory canals are about $32 \mu$ in diameter. They pass laterad of the ovary and approximately 

$50 \mu$ from the nearest longitudinal muscle strands. The dorsal excretory canals are exceedingly small. They are seldom discernible, but may be made out in certain instances in the region where the reproductive organs attain their greatest development. They appear most prominently in the region where the testes first become differentiated and here they often have a diameter of $8 \mu$. They may be observed in the region of the scolex, where they sometimes anastomose with the other excretory canals.

Commissures of the ventral excretory canals may be seen in the region where the reproductive organs first differentiate from the medullary parenchyma. These have a diameter of about $3 \mu$.

The excretory system is continuous from one proglottid to another throughout the strobila, as the ventral canals may be seen extending from one proglottid to the following one without a break. In the ripe proglottides they present lateral undulations, due to their position exterior to the parauterine capsules.

In some places crystals were distinguished in the ventral canals. They range in size from 2 to $8 \mu$, are spherical in shape, and provided with sharp spines.

Nervous System. The two main lateral nerve trunks run

parallel and in closento the dorsal and ventral excretory vessels, being midway between them. The material at hand would not permit of extensive study of the nervous tissues, and none of the nerves or ganglia in the scolex could be made out satisfactorily.

Reproductive System. The genital rudirnents first make their appearance at a distance of from 2 to $3 \mathrm{~mm}$. from the tip of the scolex. They appear here merely as a dark streak running through the center of the proglottides. The diameter of the worm in 

this region is about $0.48 \mathrm{~mm}$. The testes become differentiated from the parenchyma before the other reproductive organs. The ovary next arises, and the vitelline gland forms dorad of the latter almost immediately afterwards.

The differentiation of the testes is visible 3 to $4 \mathrm{~mm}$. from the scolex. No external segmentation is apparent at this point. The internal, or genital segmentation can be distinguished however, the segments being 0.04 to $0.05 \mathrm{~mm}$. Ionf.

All of the reproductive system, except the cirrus sac and vagina, is accomodated within the medullary parenchyma of the proglottid (Fig. 4.). The genital pores are lateral and marginal, and alternate irregularly, with no tendency whatever towards regularity as described for Cylindrotaenia (Jewell 1916:186). The cirrus sac and vagina open into the genital atrium dorsad of the excretory canals and main nerve trunk.

Male Organs. The male organs are situated dorsally in the proglottid and the female organs ventrally. The testes are two in number, and are about $67 \mu$ in their lateral and dorso-ventral diameters, at their greatest development. They are lenticular in shape and circular in cross-section, the antero-posterior thickness averaging $40 \mu$. This compression in the antero-posterior direction may be due to the contraction of the worm when killed, so the organs are probably spherical in shape in the Iive worm. A thin membrane surrounds each testis and is continuous with the walls of the vas efferens. The vasa efferentia, one from each testis, meet to form the vas deferens, near the testis on the poral side of the proglottid. The vas deferens leads ventrad almost as far as the vitelline duct, then forms a loop by passing dorsad on the poral side of the testis to a point on a horizontal line extend- 

ing through the center of the testis. After another short $100 \mathrm{p}$ leading ventrally it passes into the cirrus sac. The course of the vas deferens varies somewhat in different instances, and in some cases the loops are not so pronounced.

The cirrus proper is surrounded by parenchymatous tissue composed of small cells with spherical nuclei. The whole length of the vas deferens evidently acts as a seminal vesicle, as spermatozoa were frequently found in it at different points in its course. The cirrus pouch is flask-shaped and is about one and a half times as long as it is broad. The length averages $48 \mu$, and the diameter $31 \mu$. Lifany instances of protruded cirri were observed.

Female organs. The single ovary is a spherical organ, lying in the ventral half of the medullary region and slightly to the poral side of the proflottid. The diameter is approximately the same as that of the male gonads, averaging $67 \mu$. It is made up of numerous spherical cells, each enclosed in a capsule. The capsules average about $12 \mu$ in diameter. The vitelline gland is also spherical in shape. It lies dorso-laterad of the ovary, but ventrad of the genital pore. Its diameter averages $35 \mu$. The vitelline duct is directed laterad, meeting the oviduct, which extends laterad and dorsad. The oviduct is continuous with the vagina, which in turn leads ventrad to the cirrus pouch, running adjacent to it from the inner end of the latter. A delicate sheath surrounds the female organs, but it could not be determined whether the same sheath also enclosed the cirrus pouch and vas deferens.

The anlage of the uterus can be distinguished 12 to 14 mm. from the scolex. The uterus is horse-shoe-shaped in appearance (Fig. 5.). It arises from the medullary parenchyma and soon almost completely surrounds the vitelline gland. The ovary and 
testes break down simultaneously, although the ovary completely disappears before the testes. At its maximum development about 18 to $20 \mathrm{~mm}$. from the tip of the scolec, the uterus fills the larger portion of the proglottid, especially in the lateral diameter. The eggs here are $16 \mu$ in diameter, and appear to be more nearly spherical than in later stages. They are in the early stages of cleavage. The internal segments, at the time the reproductive organs break down, and the uterus becomes filled with eggs, are $0.11 \mathrm{~mm}$. long. The uterus breaks down early, about 22 to $24 \mathrm{~mm}$. behind the scolex, and is replaced by the parauterine organs.

Parauterine Organs. These structures arise from the parenchyma adjacent to the uterus. The strands of the meshrork of which they are composed soon arrange themselves parallel to the uterus on the anterior side of the proglottid. The whole structure from this stage on grows very rapidly. The tissue migrates inwards, replacing the uterus by capsules, and surrounding the eggs at the same time (Figs. 6, 7.). The capsules are early seen to have welldefined walls (Fig. 6). All trace of the ovary disappears, but the remnants of the testes apparently persist as long as any trace of the uterus itself can be found.

From eight to twelve truncated or flask-shaped cones appear, arranged very regularly, in two parallel rows (Figs. 8, 9). There are from four to six capsules in each row, their usual number being five. The number is as a rule the same in each of the two rows. One row is dorsal, and the other ventral. The capsules of the two rows come together in the center of the proglottid and are separated from each other by a sort of raphe, which is composed of numerous small, spherical and thickly massed cells, that stain a dark gray with hematoxylin. The longitudinal axes of the cones 

correspond in a general way to the longitudinal axis of the worm. The basal portion of the capsules is in the posterior portion of the proglottid. A meshwork of fine fibers together with a fine granular tissue adjoins the capsules in the basal portion. The apical portion, capped in each instance by the darkly stained cell-gland secretion, is situated in the anterior portion of the proglottid. The minute cells from which the secretion is emitted, are easily distinguished at the most anterior end of the whole arrangement, and just adjacent to the capped secretion itself. The apices of the cones of the tro rows diverge from each other, so that they cannot both be seen in the same microscopic plane except when viewed laterally (Figs. 8, 9). The length of the cones increases as the proglottides become elongated. At the time when the cones attain their greatest length, at a distance of 60 to $70 \mathrm{~mm}$. from the head, they measure approximately $0.11 \mathrm{~mm}$. The width of the base of a cone averages $0.06 \mathrm{~mm}$. In the lateral diameter, and $0.09 \mathrm{~mm}$. in the dorso-ventral diameter. The apical portion, the capped secretion,averages $0.03 \mathrm{~mm}$. in width, and $0.07 \mathrm{~mm}$. dorso-ventrally.

The eggs, occupying the basal portion of a cone, vary in number from three to six, but are more commonly four, in each capsule. They are oval, averaging $43 \mu$ in length, and $31 \mu$ in diameter. The embryos, within the eEgs, are still in the spherical stage, and average $19 \mu$ in diameter. The eggs have a shell about $3 p$ thick. Only a single thin membrane could be distinguished surrounding the embryo.

In the later stages of development, and with the further elongation of the proglottid, the position of the cones shifts, w ith no definite regularity in regard to position they may assume to the axis of the worm (Fig. 10). Their shape also changes. 
By the time the proglottides have become ripe, or detached, the cones have become more spherical, especially in the apical portions, which now appear larger than the basal region. This growth takes place at the expense of the surrounding parenchyma, the latter furnishing the nourishment necessary for the growth of the capsule. The fact that the parenchyma is much less dense at this stage than in earlier stages is easily demonstrated in cross-sections of the proglottides. Some of the eggs migrate from the base of the cone into the apex. The bases of the cones remain clustered together, and the capsules do not become scattered throughout the parenchyma. The apical portions, however, spread apart from each other irregularly in all directions. This is caused by the total disappearance of the raphe, composed of the numerous small, spherical, cells, which heretofore held the capsules together in the two parallel rows. The capped secretion spreads out over the apex of each capsule. Portions of the fibrous and granular tissue, at the bases of the cones may become broken off and migrate into the parenchyma. This complete arrangement may be distinctly seen in the Jetached proglottides. Nothing is known of the further development. The eggs evidently become liberated by the subsequent rupture of the proglottides. 

The form under consideration bears striking resemblances to Nematotaenia dispar (Goeze 1782). There is a marked similarity in external form, and in the limitation of marked segmentation to the posterior end. Both the male and female reproductive organs are similar in shape and position, and they are identical in number in both species, there being two testes, and the ovary, vitellaria, and uterus being single in both cases. The chief difference between the two reproductive systems is in the cirrus pouch. In Nematotaenia this is tubular, and about ten times as long as broad, while in the present form the cirrus pouch is flask-shapod, and about one and a half times as long as it is broad. The uterus in both forms is horse-shoe-shaped, and breaks down early.

The most marked differences between the two forms lie in the development, position, and number of the parauterine organs. In Nematotaenia dispar there are developed a varying number of small para-uterine organs. The ripe proglottides show from thirteen to thirty capsules which are scattered, with no regularity, throughout the parenchyma. In the new worm, the number of parauterine organs is limited, there being from eight to twelve. The more mature proglottides show the same number of capsules, very definitely arranged in the two parallel rows as described.

The only description extant of Taenia pulchella Ieidy 1851, is much too meager to permit of a sitisfactory comparison with other forms. It may be identical with any one of several species since described. It has general similarities with the form under consideration, such as its occurrence in the same host genus, and its 

external appearance. Ho description whatever, is given of any internal features.

Certain marked similarities occur between the new species and Cylindrotaenia americana Jewell 1916. In Cylindrotaenia the cylindrical form also occurs, and the segmentation of the strobila is evident at the posterior end only. In internal structure, the musculature of the two species is very similar, the longitudinal muscles being well developed, the subcuticular muscles only slightly so, and the dorso-ventral lacking, in both species. While in both forms the male reproductive organs are limited and definite in number, in Cylindrotaenia there is only one, -in the new form two - testes. In the former the vas deferens leads straight to the cirrus, while in the new worm there are various undulations. The female reproductive organs are very similar.

Again, the most marked difference between the two species occurs in the number and position of the parauterine capsules. In Cylindrotaenia, two truncated cones appear, one dorsal and one ventral, the parauterine capsules being thus definitely limited. In the form here described, the capsules are also limited, although not so definitely, and they are more numerous than in cylindrotaenia, being eight to twelve in number, with the regular arrangement previously noted. 



\section{SYSTELATIC POSITION}

Taenia dispar was placed by Weinland (1858:53) in his new genus Proteocephalus. Later investigations have shown that there is great dissimilarity in the structure of Taenia dispar and the now recognized members of the genus Proteocephalus. Its position in this genus cannot be retained.

In Luehe's revision of the Cyclophyllidea (Iuehe 1910) a new family, Nematotaeniidae, has been created for the reception of Nematotaenia dispar (Goeze 1782). This classification is based chiefly on the external form of the worm, and on the host in which it is found. It ignores completely, certain essential considerations of development and morphology, which relate it more closely to other forms.

Fuhrmann (1908:29) and Ransom (1909:88) have placed Nematotaenia in the subfamily Paruterininae, with six other genera, Paruterina Fuhrmann, 1906; Culcitella Fuhrmann, 1906; Rhabdometra Kholodkovski, 1906; Anonchotaenia Cohn, 1900; Metroliasthes Ransom, 1900; and Biuterina Fuhrmann, 1902. Following is Ransom's diagnosis of the subfamily (Ransom, 1909:85): "Hymenolepididae; Scolex usually armed, rarely without rostellum. A single set of reproductive organs in each segment. Uterus simple or double with a single parauterine organ or multiple with several parauterine organs, into which the eggs pass in the final stage of development of the segment. Adults in birds and amphibia." Paruterina Fuhrmann, 1906, is designated as the type genus.

Nematotaenia differs greatly from the other six genera included in this subfamily. This is evidenced by its cylindrical 

form, its two testes, as compared with the numerous and indefinIte number in the other genera, the early deseneration of the uterus, and its numerous parauterine capsules.

Jewell (1916), after describing Cylindrotaenia, creates a new family for its reception, and includes Nematotaenia. This new subfamily is characterized as follows: "Cylindrotaenianae: Cylindrical Dilepinidae having one or two dorsally placed testes, ovary and vitellaria ventral, vitellaria dorsal to ovary. Proglottias distinct at the posterior end only. The uterus breaks down early and the embryos are later enclosed in parauterine capsules." The same writer considers Taenia pulchella Ieidy as probably belonging to this subfamily.

From the previous description of the new form, it is seen that it belongs in this subfamily. However, because of the great differences in the number and arrangement of the parauterine capsules, it cannot be placed in either the genus Nematotaenia or the genus Cylindrotaenia. The definite, regular, arrangement of the capsules in two parallel rows would make it generically distinct.

It is therefore necessary to create a new genus for the reception of this form, the diagnosis of wich would read as follows: Distoichometra. (the name referring to the two-rowed arrangement of the parauterine capsules): scolex unarmed, without rostellum. Body generally circulat in cross-section, or nearly so. Genital pores alternating irregularly. Testes two in number, dorsal Cirrus pouch approximately one and one-half times as long as broad. Ovary ventral. Uterus horse-shoe-shaped, breaking up early into two parallel rows of egg-capsules, 4 to 6 in a row. Capsules hold 3 to 6 eggs each. After breaking up of uterus, capsules remain 

clustered together and do not become scattered throughout the parenchyma.

Type species Distoichometra bufonis, gen. nov., sp. nov., with characters of the genus. From the intestine of Bufo lentiginosus.

\section{ACKINOWLEDGMENTS}

The writer wishes to express his thanks to Nr. T. B. Magath, for the use of the material upon which the present study is based, and to Professor Henry B. Ward, under whose supervision the work was done, for his helpful criticisms and suggestions. 



\section{IITERATURE CITED}

Fuhrmann, otto

1895. Die Taenien der Amphibien. Zool. Jahrb., Abt. Anat., Jena, 9:207-216.

1908. Die Cestoden der Voegel. Zool. Jahrb., Jena, Supplement 10, no. 1, 1-232.

Goeze, J.A. E.

1782. Versuch einer Naturgeschichte der Eingeweidewuermthierisches Koerper. Blankenburg. 471 pp., 35 pls.

Jewell, Minna E.

1916. Cylindrotaenia americana nov. sp. from the Cricket Frog. Journ. Paras., Urbana, 2:181-292.

Johnston, T. Harvey

1912. Notes on Some Entozoa. Proc. Roy. Soc. Queensland. Brisbane, 24:63-91.

1916. Helminthological Notes. Mem. Queens. Mus. Brisbane, 5:186-196.

Leidy, Joseph

1851. Contributions to Helminthology. Proc. Acad.

Nat. Sci. Phila., 5:239-244.

Luehe, Max(imillian Friedrich Ludwig)

1899. Zur Bentniss einiger Distomen. Zool. Anz., Leipzig, 22:524-539.

1910. Parasitische Plattwuermer. II: Cestodes. In Die Suesswasserfauna Deutschlands, Jena, 18: iv + 153, 174 figs. 

Ransom, Brayton Howard

1909. The Taenioid Cestodes of North American Birds.

Bull. U. s. Nat. Mus., Washington, No. 69.

Schmidt, otto

1855. Ueber den Bandwurn der Froesche Taenia dispar, und die geschlechtslose Fortpflanzung seiner Proglottiden. Zeitsch. ges. Naturw., Originale, Halle, $5: 1-13$.

Stiles, Charles Wardell, and Hassall, Albert

1912. Index Catalogue of Nedical and Veterinary Zoology; subjects Cestoda and Cestodaria. In Bull. 85, U. S. Public Health and Mar. Hosp. Serv., Washington,

Weinland, D. F.

1858. Human Cestoides. An Essay on the Tapeworms of Man. Cambridge, 93 pp., 12 figs. 



\section{EXPLANATION OF PLATE}

a. Apical portion of parauterine organ.

b. Basal portion of parauterine organ.

c. p. Cirrus pouch.

e. Egg.

e. d. Dorsal excretory canal.

e. v. Ventral excretory canal.

g. a. Genital atrium.

m. Longitudinal muscle.

n. Iongitudinal nerve.

o, ovary

od. oviduct p. u. Parauterine organ.

r. Raphe.

s. Gland-cell secretion.

sp. Septum between proglottides.

t. Testis.

u. Uterus.

V. Vagina.

vi. Vitelline gland.

vi. d. Vitelline duct.

vd. Vas deferens.

ซ. Capsule wall.

Fig. 1. Toto mount of scolex of young worm.

Fig. 2. Cross-section of scolex through tip of suckers.

Fig. 3. Cross-section of scolex through center of suckers.

Fig. 4. Cross-section of mature proglottid.

Fig. 5. Cross-section through mature proglottid; somewhat later stage than Fig. 4.

Fig. 6. Cross-section through apical portion of parauterine organs. Fig. 7. Cross-section through basal portion of parauterine organs. Fig. 8. Dorsal view of ripening proglottid, with parauterine capsules formed. Toto mount.

Fig. 9. Lateral view of a slightly earlier stage than Fig. 8. Toto mount. 

1.23.

$m$

m.

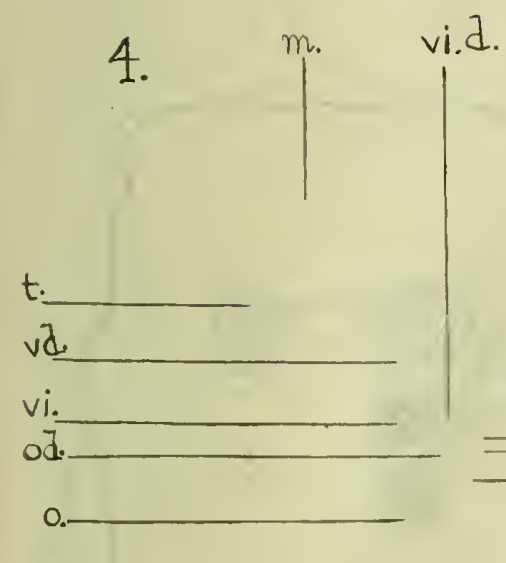

6.

7.
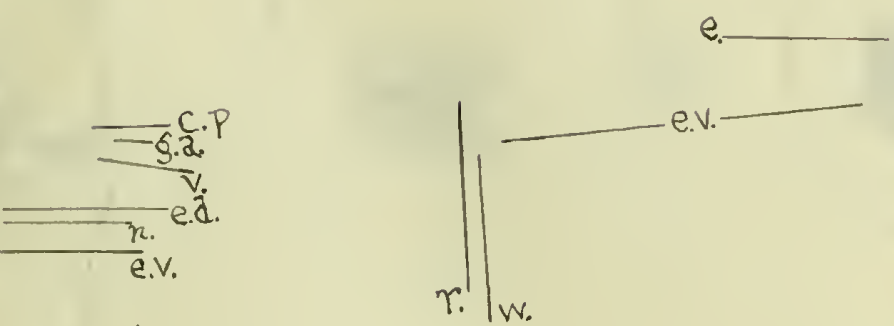

8.

9.

5.
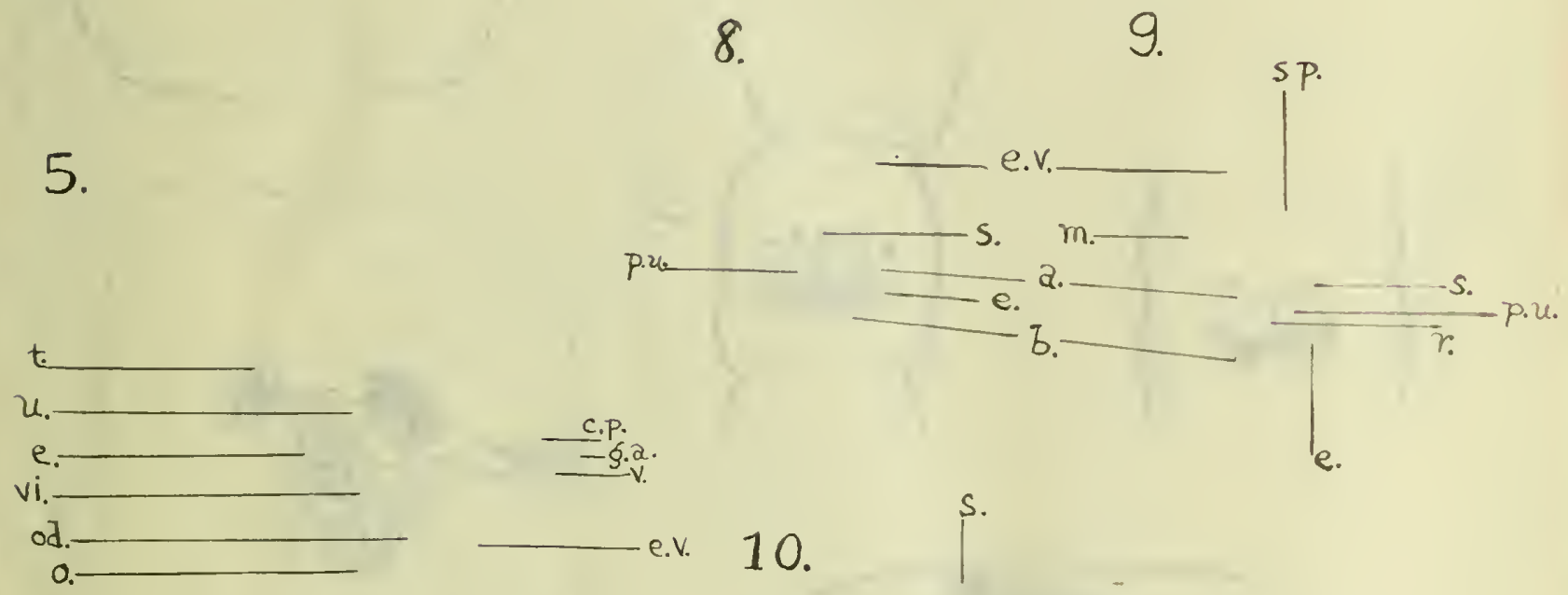

10.<smiles></smiles>

e. p.u.<smiles>CC(C)O</smiles> 
5

anty

s

a-

B

.5

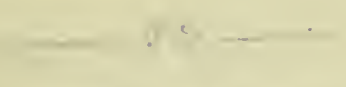

a. , .6-

$\frac{2}{25}$

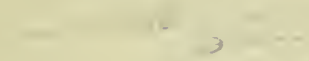

$+-c^{3}$

$$
\text { (1) }
$$

8 $-y$

.5

....

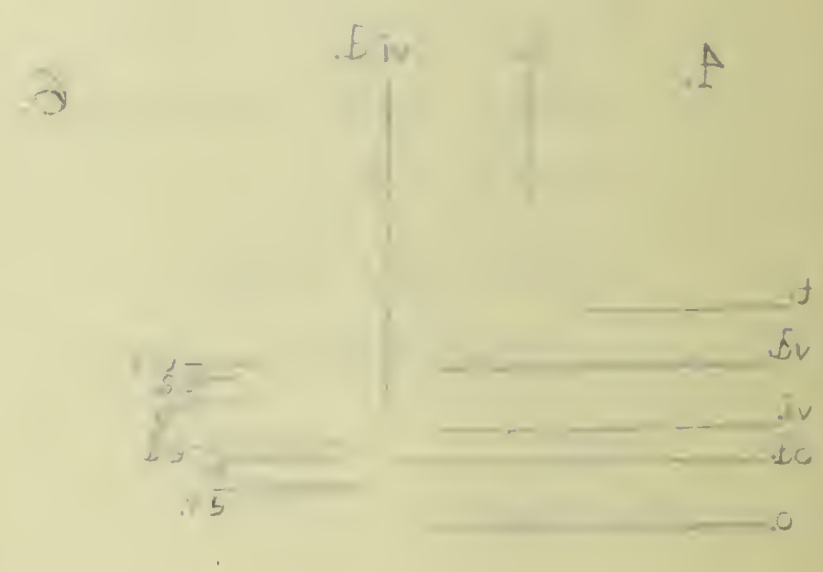

.

8

$-4$
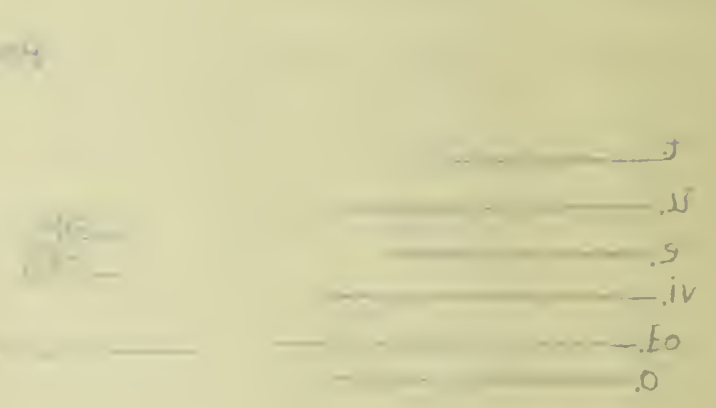

$+4+3$

int 


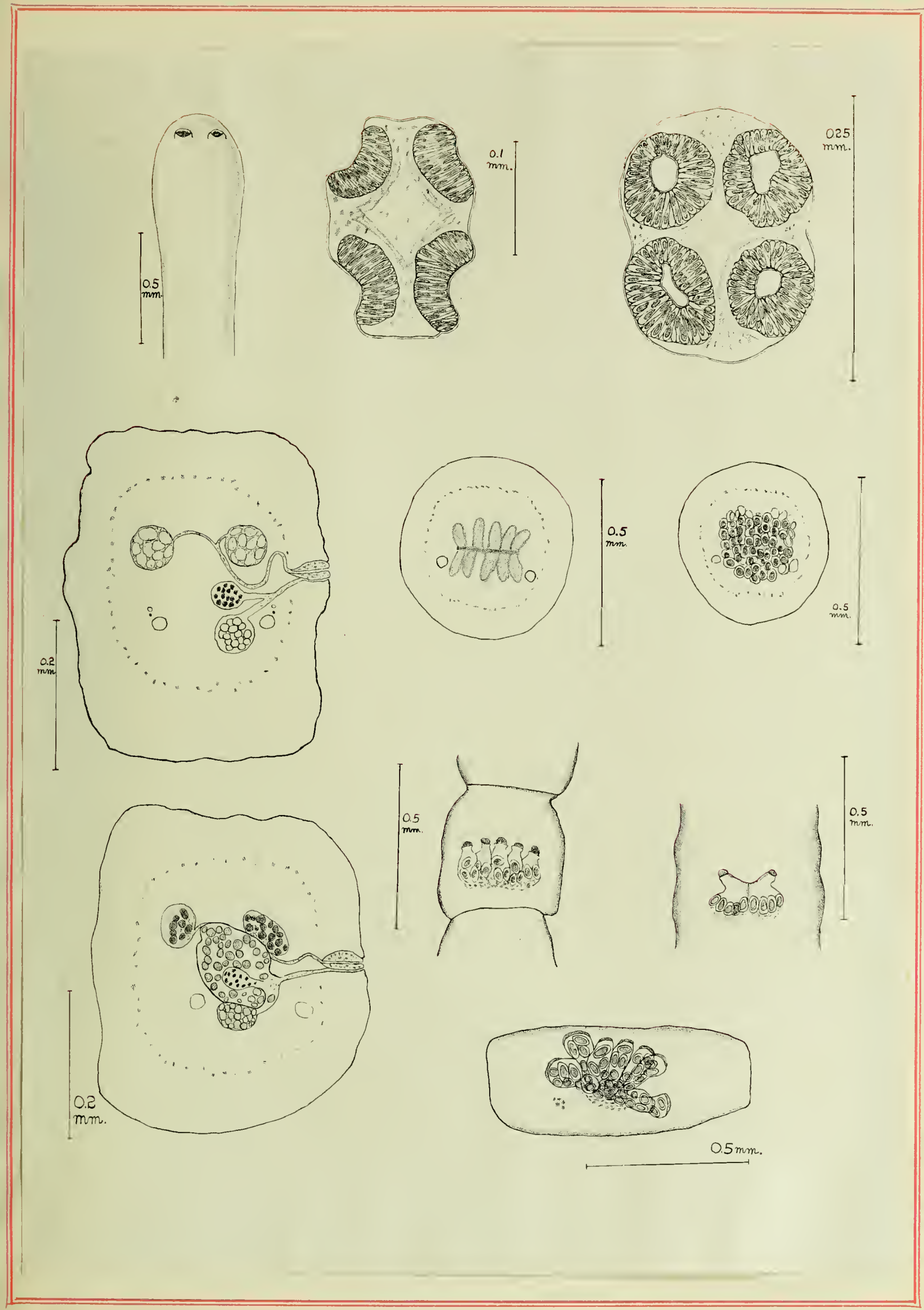





\section{-}

1

เ

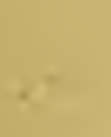

$=$. 
UNIVERSTY OF ILUNOLURBAHA

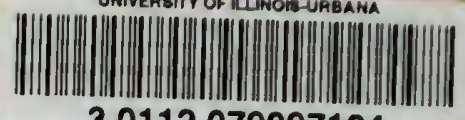

30112079097124

t

4 